Vol. XXIII No $1 \quad 2017$

\title{
HUNGARIAN SECURITY POLICY AND THE MIGRANT CRISIS (2015-2017)
}

\author{
Diana IVANOVA \\ "Neofit Rilski" Sout-West University Blagoevgrad, Bulgaria \\ velevad@abv.bg
}

\begin{abstract}
The purpose of this article is to present the Hungarian security policy over the last two years, focused on the migrant crisis. This policy is explained on the basis of the National Security Strategy. According to the Strategy, the migration is treated as a natural and at the same time complex phenomenon, bringing economic and demographic advantages and, at the same time, carrying public and national security risks. It is concluded that resolving the crisis is one of the most important priorities of the Hungarian security policy. The paper highlights the differences between the Hungarian security policy and the official policy of the EU. Like the other members of the Visegrád Group, Budapest is against the quota system for the allocation of migrants. The position of Hungary is that the discussion of the migrant problem both in the Group and at EU level should be based on the concept of effective solidarity. The country supports European integration of the Western Balkans. The study is based on documents, mainly of the Visegrád Group, and materials from the media.
\end{abstract}

\section{Keywords: migrant crisis, security policy, Visegrád Group, European Union}

\section{Introduction}

The international situation changed dramatically in the last few years as evidenced by increasing number of terrorist acts in different states. Migration crisis which has been exacerbated in the last three years caused a change of policy to the security of European countries and often became the subject of disagreement between them. The official policy of the European Union (EU) was not approved by the countries of Central Europe and the Hungarian Prime Minister Viktor Orbán became its most serious critic. He is against the quota system for allocation of migrants, which is proposed by Brussels, and calls for acceleration of the European integration of the Western Balkans. The importance of Hungarian security policy increases because on the July 1, 2017 the country takes over the rotating presidency of the Visegrad Group (V4).

The presentation of the Hungarian security policy, aimed at resolving the migrant crisis, is based on documents - of both the Hungarian Foreign Ministry and the Visegrad Group, as well as on materials from the media.

\section{Hungarian security policy}

The main directions of the Hungarian security policy are enshrined in the National Security Strategy, elaborated in 2012 [1]. On the basis of values and interests and an analysis of the security environment this document defines the national objectives, tasks and comprehensive governmental tools for Hungary with a view to asserting its national security interests in the international political and security context. In today's continuously changing security environment challenges, risk factors and threats appear on several levels - at individual, community, state, regional and also global level. The management of this challenges requires comprehensive and 
coordinated political, economic and - if necessary - military action. The authors of the Strategy emphasize that in our globalised world of today, security does not start at country borders, because the "distant security risks and challenges and sources of danger can cross our borders with dramatic speed" [2]. The fundamental security interests of Hungary include the protection of its sovereignty, territorial integrity and constitutional order, the stability of the country, its economic, social and cultural development and the upholding of human rights and fundamental freedoms. Completely logical membership in NATO and the EU provides the basic framework of Hungary's security policy. The stability of the Eastern and Southern Neighborhood Hungary and the spread of democratic values are of paramount importance for the security of the country [3].

The document, which is analyzed in the article, has been taking notice of the migration. According to the Strategy, the migration is treated as a natural and at the same time complex phenomenon, bringing economic and demographic advantages and, at the same time, carrying public and national security risks. Some of Hungary's borders will remain as the external border of the EU or the Schengen Area for the foreseeable future, with tasks of and responsibilities for managing that border [4]. Despite the existence of strategy before 2015 in Hungary there has not been much talk about the refugees. For the Hungarians this question seemed to be an exotic problem of distant countries. But neither for Brussels nor for the Hungarian Government it could have caused surprise that the Syrian War and the advance of the Islamic State sooner or later will be felt in Europe. It was clear (or at least it was supposed to be), that sooner or later the refugees could reach us because Hungary is situated in the Western Balkan migration and smuggling route. Unfortunately, the Hungarian government like most of the governments of the EU member states and Brussels - instead of being prepared for the expected larger influx of refugees, was sitting on its laurels [5].

Prime Minister Orbán has vowed to seal Hungary's southern border with Serbia from September 15, imposing tougher penalties for illegal entry and setting up transit zones [6].

Orbán says his government is merely trying to uphold EU rules by insisting that all migrants register in Hungary, doing a job he says Greece - the first EU state many of them enter - has failed to do by letting them head north across the Balkans.

$\mathrm{He}$ has also invoked Europe's historic Christian heritage, suggesting it is under threat from the mainly Muslim migrants who are anyway only coming - he argues in search of a higher material standard of living. "We like to have kebab kiosks, to buy lamb from the Syrian butcher at Easter, but we don't want to see the numbers (of Muslims) suddenly radically rise," Orban told Hungarian ambassadors on Monday, in characteristically colorful language [7].

According to the Strategy Hungary attaches great importance to the policy of security cooperation and action will be held in the framework of multilateral organizations. The policy of the Visegrád Group on the migrant crisis can be viewed in this regard. This policy opposes Hungary, Poland, Czech Republic and Slovakia of EU.

\section{Hungarian security policy within the framework of the Visegrád Group}

The most serious problem on which Brussels and the Visegrád Four have different positions is undoubtedly the migrant issue.

The Central European countries are firmly against the quota principle in the allocation of migrants and this position of theirs was categorically stated during the Czech presidency of the Group (1 July 2015 - 30 June 2016).

After the meeting held in Prague on the September 4, 2015 the leaders of the four countries came out with a joint statement to "preserve the voluntary nature of the EU measures" concerning migrants and that 
"any proposal leading to introducing mandatory and permanent quotas... would be unacceptable" [8]. As a response to calls for EU solidarity on migration, the Visegrád countries reminded they "have continuously pointed out that an effective management of the root causes of migration flows is the key element" in any solution [9].

While inflows of refugees when trough the Hungarian border in late Summer 2015 before the right-wing and conservative Government built a fence on the southern border, the parliamentary group of the Hungarian Socialist Party (MSZP) formulated a year later a proposal with farreaching demands addressed to the Government for a change in the current migration policy. The parliamentarians called upon the Government to establish a specialized border policing directorate and to initiate an institutionalized cooperation with other EU member state [10].

At the beginning of 2016 with the deepening of the migrant problem the policy of the Visegrád Group has intensified. The leaders of the four countries declared it would support plans to tighten border controls on the Balkan route, Greece and Turkey should fail to implement Ms Merkel's plans to limit the flow of migrants.

Hungary's Prime Minister Viktor Orbán claimed Germany's "welcome culture" towards refugees had "encouraged terrorism and spread fear" [11].

The migrant issue is extremely important for the Polish Presidency, which is confirmed by the fact that the migrant crisis is ranked first in the first priority of the Programme of the Polish Presidency, namely "1. Strong voice of the V4 in the European Union: coordination of the European agenda and cooperation on key challenges" [12].

Regarding the reform of the Common European Asylum System, in particular the Dublin system, the V4 countries focus on the opposition to any changes that would lead to the introduction of any permanent and binding mechanism, redistribution or would substantially reduce Member States' competence in this area. Their efforts are primarily directed towards providing assistance to third countries and strengthening the cooperation with them to address the root causes of migration pressure [13].

What is envisaged is the continuation of cooperation within the EU Emergency Trust Fund for stability and addressing root causes of irregular migration and displaced persons in Africa. As a group of donors, the V4 countries will work out common positions before meetings of the Board and Operational Committees of the Fund. The Presidency continues the coordination of the initiative for joint parallel local humanitarian projects in Jordan and Syria.

The formulated in the Programme priorities were discussed at a meeting of interior ministers of the four countries held on July 11, 2016 in Warsaw. There was an agreement on the constructive position of the Visegrád countries in the area of migration and border issues including: 1) continuous efforts to ensure adequate protection of the external borders of the EU Member States; 2) increasing support to the third countries; 3) the lack of consent for any mandatory and automatic mechanisms [14].

The Visegrád Group countries reaffirm their stance against the quota principle for the allocation of migrants at the summit of the EU in Bratislava (September 16, 2016). The four states emphasize upon the protection of the external borders of the Schengen area and the entire EU. The issue of security is closely linked to migration, which is a big problem for five of the Member States. That is why V4 insists on basing the migrant policy on the principle of "flexible solidarity" [15].

The Hungarian Prime Minister Viktor Orbán assesses the meeting in Bratislava as unsuccessful since a change of the migration policy of Brussels has not been achieved. According to him, in the EU there continues to prevail a "self-destructive and naive immigration policy" as "on this occasion the summit had focused more on speeding up 
the process of distributing migrants across Europe than on stopping them at the border of the Schengen Area" [16].

The referendum in Hungary can be interpreted as a reaction against this policy of Brussels. It was held on October 2, 2016 and $98 \%$ of the Hungarian voters rejected the EU plan for the state to adopt the mandatory quota of refugees [17]. Thus with the support of the society Orbán has legitimized his policy. However, the claim of Jan Culik that by the referendum "Orbán also wanted to stoke a cultural and political counter-revolution throughout the European Union" [18] is far-fetched.

To realize the main priority of the Polish Presidency of importance is the meeting of interior ministers of the Visegrad Group countries, held on November 21, 2016 in Warsaw [19].There the ministers once again expressed their disagreement with the proposed EU system for moving refugees. They are united around the opinion that further discussion of the migrant problem in the Group and at EU level should be based on the concept of effective solidarity[20].

At the meeting in Warsaw interior ministers announced the creation of a Migration Crisis Response Mechanism, whose aim is to achieve a more effective coordination between the respective institutions responsible for migration. In this way there can be an appropriate response to relevant challenges in providing assistance to refugees in countries outside the European Union. The center will be run by Poland [21]. It is a counter-proposal to the system of mandatory quotas for the resettlement of refugees, proposed by Brussels.

Participants in the meeting of the Visegrád Four, including representatives of Austria, Belgium, Bulgaria, Croatia and Slovenia, stressed the need to improve the protection of the EU borders and encourage the return of migrants to their home countries. To escape from the migration crisis, they believe that the European Union should abandon plans for refugee resettlement and to pursue a policy of returning migrants that have arrived in the EU.
The problem of illegal migration is distinguished as one of the main challenges facing Europe at the meeting of foreign ministers of the Visegrád Group, too, which was held on November 29, 2016 in Warsaw, attended by the High Representative of the Union for Foreign Affairs and Security Policy and the VicePresident of the European Commission Federica Mogherini [22]. At the meeting the Ministers of the Visegrad countries adopted a joint declaration on the policy of EU enlargement, in which they reaffirmed their support for the European aspirations of the Western Balkans states. They emphasize that the reliable and effective policy of enlargement is a strategic investment in the security of Europe [23].

On January 31, 2017 a V4 meeting of experts on the mechanism of migration crisis was held. The meeting served as a follow-up to the decision of V4 ministers of interior adopted on November 21, 2016, establishing the Mechanism.

The Visegrád countries seek to solve the problem outside the borders of the Old Continent, in which case it is not about xenophobia, as these countries are often blamed for, but it is about a pragmatic and nationally responsible foreign policy. The four countries emphasize upon the protection of the external borders of the Schengen area and the entire EU.

\section{Conclusions}

The analysis of key documents on the migrant crisis, which determines the policy of Hungary on this issue, allows the drawing of a few conclusions. First, there stands the conclusion that the work on resolving the crisis is one of the top priorities of the Hungary's security policy. The countries of the Visegrád Group categorically rejected the quota principle for the allocation of migrants. In return, the position of Hungary - so as of Poland, the Czech Republic and Slovakia - is that the discussion of the migrant problem both in the Group and at EU level should be based on the concept of effective solidarity. The 
leaders of the Visegrád Group see the realization of this concept in two interrelated ways. The first one provides for assistance in the protection of the external borders of the EU (including the Republic of Macedonia) and there ensued the second one - support to accelerate the EU accession of Western Balkan countries, which will enhance security in the region.

The drawn conclusions give grounds for the policy of Hungary on the migrant problem to be defined as a reasonable one with a vision for the future. In support of this, there can be interpreted the partial change in the position of the German Chancellor Angela Merkel in the first weeks of December - migrants who have been refused a refugee status or have committed crimes have to be deported. This change gives hope that the decisive Hungary's policy within the Visegrád Group on the migration crisis will contribute to its successful resolution.

\section{References}

[1] Ministry of Foreign Affairs of Hungary. Hungary`s National Security Strategy. 2012.

[2] Ibid., p. 5.

[3] Ibid., p. 8.

[4] Ibid., p. 17.

[5] Benyik, M. Refugee crisis and Hungary. http://www.transform-network.net/blog/blog2015/news/detail/Blog/refugee-crisis-and-hungary.html (available on 31.03.2017).

[6] Than, K. Hungary's Orban plays for high stakes with tough stance on migrants. http://www.reuters.com/article/us-europe-migrants-hungary-orbanidUSKCN0R82B920150908 (available on 07.04.2017).

[7] Ibid.

[8] Gotev, G. Visegrad countries trigger crisis ahead of EU refugee summit. 22.09.2015. http://www.euractiv.com/section/justice-home-affairs/news/visegrad-countries-triggercrisis-ahead-of-eu-refugee-summit/ (available on 18.03.2017).

[9] Refugee quotas 'unacceptable' for Visegrad states. 4.09.2015. https://euobserver.com/migration/130122 (available on 18.03.2017).

[10] Toth, B. Handling the refugee crisis: Progressive views from Hungary.https://progressive-europe.eu/handling-the-migration-crisis-progressive-views-fromhungary/ (available on 9.04.2017)

[11] Refugee crisis: Eastern Europe opposes Angela Merkel's policy on asylum seekers. Independent. 16.02.016

[12] http://www.independent.co.uk/news/world/europe/refugee-crisis-eastern-europeopposes-angela-merkel-s-policy-on-asylum-seekers-a6877916.html (available on 26.03.2016).

[13] Programme of the Polish Presidency of the Visegrad group 1 July 2016 - 30 June 2017. Ministry of Foreign Affairs, Republic of Poland, Warsaw 2016, pp.8-9.

[14] Ibid.

[15] Visegrad Bulletin (1/2016), Review of the most important events In July and August 2016. http://www.msz.gov.pl/en/foreign policy/europe/visegrad group/polish presidency of the_visegrad_group_2016_2017/visegrad_bulletin_1_2016_jsessionid $=21525 \mathrm{D} 3182$ A95EE5D1F7AB7341DCĀ7BB.cmsap2p.

[16] Вишеградската четворка постави ултиматуми на Брюксел. In: https://www.actualno.com/europe/vishegradskata-chetvorka-postavi-ultimatumi-nabruksel-news_563395.html - (available on 15.12.2016) 
[17] Резултати от аварийно-спасителната среща на върха на ЕС в Братислава. In: http://bultimes.com/rezultati-ot-avarijno-spasitelnata-sreshta-na-varha-na-es-vbratislava/ - (available on 15.12.2016)

[18] The referendum is not valid because voters are around $45 \%$, while according to the Hungarian Constitution there must be more than $50 \%$ of voters. See more: Macdowal, A. Voters back Viktor Orbán's rejection of EU migrant quotas. In: http://www.politico.eu/article/hungary-referendum-eu-migration-viktor-orban/ (available on 25.03.2017).

[19] Culik, Jan. Hungary's invalid refugee referendum dents Viktor Orbán's antiEU 'revolution'. In: https://theconversation.com/hungarys-invalid-refugee-referendumdents-viktor-orbans-anti-eu-revolution-66424 - (available on 25.03.2017).

[20] Joint Statement of V4 Interior Ministers on the Establishment of the Migration Crisis Response Mechanism. In: http://www.visegradgroup.eu/calendar/2016/joint-statementof-v4 [20] Visegrad Bulletin (3/2016). In: http://www.visegradgroup.eu/visegradbulletin-3-2016- p.2. (available on 08.04.2017).

[21] Joint Statement of V4 Interior Ministers..., Op. cit.

[22] Meeting of ministers and representatives of 15 Central and South-Eastern European countries attended by head of European diplomacy. In: http://www.msz.gov.pl/en/foreign_policy/europe/visegrad_group/polish_presidency_of the_visegrad_group_2016_2017/meeting_of_ministers_and_representatives_of_15_ce ntral_and_south_eastern_european_countries_attended_by_head_of_european_diploma cy;jsessionid $=2 \overline{1} 830255 \overline{\mathrm{A}} 6 \mathrm{ACE} 68 \overline{\mathrm{E} C E D} 570 \overline{\mathrm{C} D} 32 \mathrm{~F} 78 \overline{4} \mathrm{E} 2 . \mathrm{cmsap}^{-} \mathrm{p}^{-} \quad-$ (available on 08.04.2017).

[23] The Visegrad Group Joint Statement on the Western Balkans, In: http://www.visegradgroup.eu/calendar/2016/the-visegrad-group-joint-(available on 08.04.2017). 